\title{
Danske Samfund for Øster Løgum sogn
}

\author{
Af Carl Rise Hansen
}

I efteråret 1933 oprettedes "Danske Samfund « i en lang række sogne i grænseområdet. Det skete for at samle danskheden over for den truende blæst fra syd. I 1940 blev organisationen udbredt til hele Sønderjylland, og de følgende år opnåede »De sønderjydske danske Samfund « et medlemstal på omkring 80.000 .

I Øster Løgum sogn var førstelærer Jens Kristensen (1894-1987) sekretær og siden formand for Danske Samfund. Svigersønnen, tidligere overarkivar ved Rigsarkivet Carl Rise Hansen, har bladet $i$ de gamle protokoller og regnskabsbilag og giver på den baggrund et eksempel på Danske Samfunds arbejde på lokalt plan. Der skete virkelig meget i de små forsamlingshuse fra 1930 'erne og frem til foreningskrisen satte ind efter krigen.

Da min svigerfader, lærer og degn i Øster Løgum Jens Kristensen, var død og hans skrivebord blev tømt, fandtes heri bl.a. en »Forhandlingsbog« for Dansk Samfund for Øster Løgum Sogn og en regnskabsbog med bilag for samme.

Protokollen er ført med Kristensens hånd og indledes med følgende: "I Efteraaret 1933 afholdtes paa Folkehjem i Aabenraa et Møde, hvortil de nationale Foreningers Tillidsmænd fra de omliggende Sogne var indbudt.

Anledningen var den nazistiske Politiks Gennembrud i Tyskland, og den nazistiske Bølge, der i den Anledning strømmede ind over vore Grænser og på sine Steder syntes at fremkalde nogen Vaklen i de danske Rækker.

Nogle nationalt vaagne danske Mænd med direktør Hammerich, Tønder i Spidsen havde derfor faaet den Idé at oprette Danske Samfund i 32 Grænsesogne, hvoraf Øster Løgum blev det nordligste.

Meningen var i hvert Sogn at optage en Liste over alle, som ønskede at regnes med blandt de Danske, og i den Forening, man saaledes fik, og som skulde bære Navnet Dansk Samfund, forsøge at stimulere Dansk Fællesskab, Foreningsliv, unges Besøg paa Højskoler og Efterskoler o.s.v.

Mødet på Folkehjem gav Anledning til, at de nationale Foreningers Tillidsmænd i Øster Løgum Sogn indbød til et Møde i Øster Løgum Kro den [uangivet] Oktober 1933. Som Talere var indbudt to af Det unge Grænseværns Forkæmpere Hsm.Chr. Nielsen fra Vollerup og Gdr. Ernst Christensen, Asserballe.

Der var voldsom Tilslutning til Mødet, Sal og Scene var optaget, og Folk stod ud gennem Døren. 
Her oprettedes Dansk Samfund for Øster Løgum Sogn, og der valgtes følgende Bestyrelse:

1) Gdr. Fr. Schmidt og

2) Invalid Joh. Paulsen, Genner,

3) Gdr. R. Callesen, Lerskov

4) Lmd. M. Midtgaard og

5) Lærer J. Kristensen, Ø. Løgum,

6) Gdr. Claudi Clausen, Hovslund,

7) Fru Pinstrup Larsen, Hjaruplund

8) Ledvogter Joh. Buhrkall, Nr. Hjarup og

9) Smedemester J. Petersen, Rugbjerg.

Bestyrelsen valgte derpaa Gdr. R. Callesen, Lerskov til formand, Smedemester Petersen til Næstformand og Lærer J. Kristensen til Sekretær og Kasserer.

Ved den første Medlemstegning, der fandt Sted i Nov. Maaned 1933, tegnede sig saa godt som alle Danske og adskillige, hvis Stilling man ikke havde været og endnu ikke var alt for sikker paa.

Dog var der nogle Danske, som havde sluttet sig til den danske Nazisme, der ønsker et venligt Forhold til den tyske. En Del af disse nægtede nu at

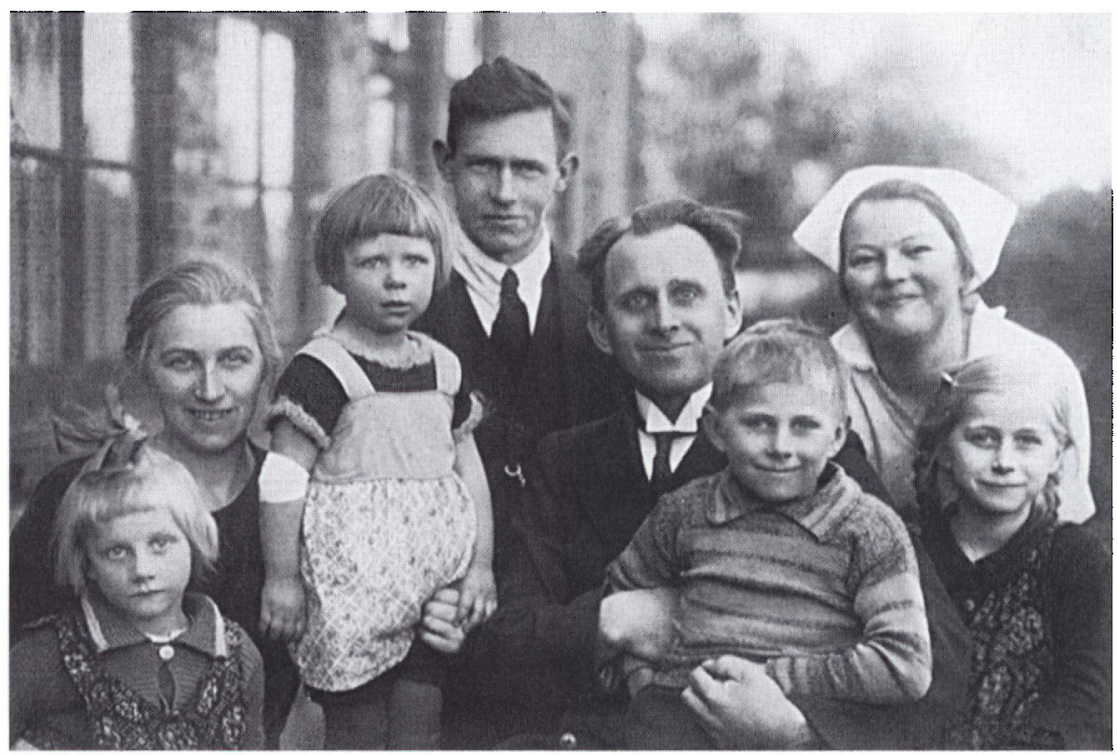

Degnefamilien i Øster Logum, fotograferet 1927 eller 1928. Larer Jens Kristensen og hustru Karen Kristensen f. Jespersen og de fire barn. Gengivet efter Senderjysk Månedsskrift 1972, s. 187. 
træde ind i Dansk Samfund. Noget stort Tal var det ikke, der paa den Maade svigtede, og ialt tegnedes i Sognet 776 Medlemmer. (Tallet senere indført)

Det var forud bestemt, at der ikke maatte opkraves Medlemsbidrag. Der var altsaa ingen Kassebeholdning, og hvad man arrangerede maatte hvile i sig selv, indtil der blev oparbejdet en Kassebeholdning".

Med denne indledning begynder forhandlingsbogen, hvorefter der berettes om møder af forskellig art.

\section{En flyvende start}

Dansk Samfund begyndte sin virksomhed med en grundlovsfest ved Genner Strand 5.juni 1934. Til festen var Snoghøj Gymnastikhøjskole indbudt, og eleverne - ca. 100 unge piger - lavede gymnastik. Festtalen holdtes af seminarielærer Eskildsen, Tønder. 580 deltagere løste adgangstegn. Entreen fra denne fest gav 289,80 kr. Nu var der oparbejdet en kassebeholdning. Men der havde været udgifter, små til annoncer i Hejmdal og Jydske Tidende, til bånd og kridt og til kørsel af klaver. Snoghøj Gymnastikhøjskole fik $100 \mathrm{kr}$. til kørsel og Eskildsen $40 \mathrm{kr}$. i foredragshonorar.

Endnu i samme måned - 24. juni 1934 - arrangerede samfundet friluftsteater i Øster Løgum og indmeldte sig nu i Sønderjydsk Teaterforening. Det blev Axel Garde-Turneen, der spillede Molbechs "Ambrosius«, bearbejdet for friluftsopførelse af Kai Holm og Thomas P. Hejle. Efter sekretærens mening $i$ »en meget udmærket Udførelse«. Da der ikke var noget fortæppe, skulle en danserinde divertere publikum i de nødvendige mellemakter. Det blev Irene Graae til musik fra Ambrosius Stubs tid af Lully og Tartini. Dansene var komponeret af Irene Graae, der akkompagneredes af pianisten Poul IngerslevJensen. Ca. 210 voksne og en del børn løste adgangstegn.

Kassebeholdningen var nu forøget. Teaterforestillingen gav 225,50 kr., hvoraf halvdelen straks udbetaltes mod Kaj Holms kvittering. De øvrige udgifter var små: til fakler 4 kr., det samme til plakater, til klaverstemning 7 kr., og så var der kaffe til skuespillerne på Øster Løgum kro $8 \mathrm{kr}$. Festpladsen var billig. Det var en toft bag Niels Møllers gård syd i Løgum by; fru Møller fik $5 \mathrm{kr}$. for arbejde i den anledning. Der kunne indbetales et overskud på $160 \mathrm{kr}$. på samfundets konto i Amtssparekassen i Aabenraa.

Det må have været med tilfredsstillelse, at bestyrelsen samledes til møde i Øster Løgum; her vedtog man at forsøge med en stor teateraften i Hovslund ny forsamlingshus i efterårets løb. Man valgte Arne Jensen-Selskabet med skuespillet "Maskinen« af Anders Olsen. Det er næppe kendt idag; men sekretæren fandt spillet godt. Aftenen - det var 6. nov. - blev vellykket med udsolgt 
hus. Der indkom $384,60 \mathrm{kr}$., men teaterforeningen havde i brev af 8 . okt. forlangt $400 \mathrm{kr}$., så der blev et mindre underskud.

På bestyrelsesmødet $\mathrm{i}$ september havde man også vedtaget at arrangere to små kunstneriske »aftener«, en i Genner med Ejner Juhl-tourneen og en $\mathrm{i}$ Hovslund med direktør Garde. I Genner opførtes 18. nov. forskellige småting ved en eftermiddagsforestilling. Der var ikke helt fuldt hus, men dog ret god tilslutning. Sekretæren fandt udførelsen god. Der indbetaltes fra Genner 50 kr., som gik videre til teaterforeningen. Med annoncer var der et lille underskud.

Den 18. december 1934 afholdt Dansk Samfund så generalforsamling i Hovslund forsamlingshus. Regnskabet udviste nu en formue på 206,20 kr.. Aftenen afsluttedes med et foredrag af seminarielærer Claus Eskildsen om Nordens sydgranse; honorar $30 \mathrm{kr}$., hvortil kom kaffe og kager til ham og hans chauffør $0,80 \mathrm{kr}$. Foredraget skal have været interessant.

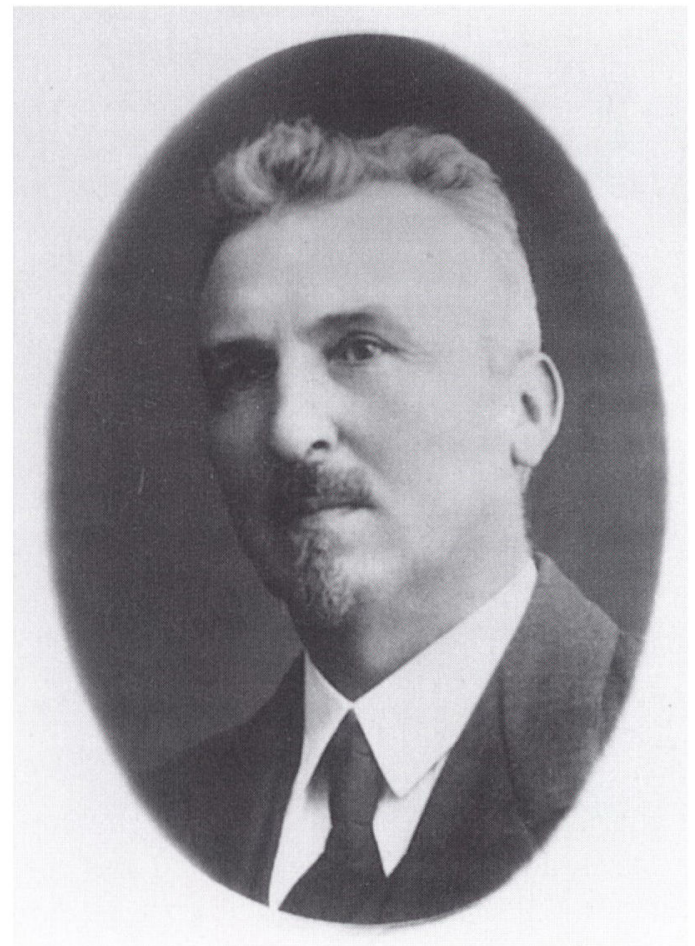

Gärdejer Rusmus Callesen, Lerskov var sognerddsformand $i$ Oster Logum 1921-32 og formand for Danske Samfund fra starten. Historiske Samlinger for Sonderjylland. 


\section{Teater og grundlovsfester i medvind}

Det nye år 1935 begyndte med kunstneraften i Hovslund forsamlingshus. Det skal have været en god aften med optræden af direktør Garde, pianist Crone og danserinden Irene Graae. 118 betalte adgangstegn á $1 \mathrm{kr}$. Halvdelen af indtægten fik forsamlingshuset. Sønderjydsk Teaterforening må have været involveret og fik i begyndelsen af marts godt $82 \mathrm{kr}$. Økonomien spillede altid en stor rolle.

Grundlovsfesten ved Genner Strand var fastlagt som en årlig fest. I 1935 talte højskoleforstander Fr. Terkelsen, Danebod om Christian Richard. Aabenraa amts landshold til den store Ollerup-fest viste gymnastik. Hovslund folkedansere dansede, og et spejderorkester spillede. Der var stor tilslutning, skønt vejret var lunefuldt. Kontrollen menes at have svigtet en del, så der indkom kun 130,20 kr. Leje af marken kostede $30 \mathrm{kr}$., foredragsholderen fik $35 \mathrm{kr}$., gymnasterne $50 \mathrm{kr}$. og transport af spejderne $15 \mathrm{kr}$.. Desuden var der trykning af et program med sange for over $30 \mathrm{kr}$., så dette arrangement kunne ikke hvile i sig selv.

En friluftsteaterforestilling søgtes ligeledes gennemført som en fast årlig fest. Her benyttedes Sønderjydsk Teaterforenings sommerspiltourné, og foreningen tog såvidt muligt hensyn til de enkelte spillesteders ønsker mht. spilledage. I en rundskrivelse af 18 . maj 1935 blev der givet oplysninger om, på hvilke dage de forskellige byer ville få tourneens besøg. I Øster Løgum skulle det egentlig have været 22. juni, men der blev byttet til lørdag 29.juni, vel ikke nogen dårlig ugedag.

Det var Olufsens gamle spil "Gulddåsen«, der opførtes. På forhånd var det oplyst, at kunstig belysning var unødvendig, ligesom der ikke skulle sørges for gulv, da man optrådte direkte på grønsværen. Dekorationer medbragtes af tourneen selv, og en fællesplakat skulle blive fremsendt i god tid forinden. Oprindeligt krævedes et klaver stillet til rådighed; men det ændredes, inden tourneen startede 11. juni i Skærbæk, således at man medbragte en tonevogn, der leverede musik under forestillingen. Klaveret kunne derfor udgå. Det var anmeldt, at der $\mathrm{i}$ forestillingen medvirkede 13 skuespillere, hvortil nu yderligere kom en overregissør med tonevognen, så nu var der 14 personer at indkvartere. Det bemærkedes, at der blandt skuespillerne var et ægtepar (fru Inga Schultz gift med Peter Paulsen); de fik logi i præstegården, mens formanden Rasmus Callesen gav husly til Bjarne Forchhammer. Hvor de øvrige fik natkvarter oplyses ikke, blandt dem var Kai Holm og Olaf Ussing.

Det var en udpræget sommertourné, der sluttede i Nordborg 7.juli, så strabadserne med fugtigkolde senge var næppe så store. Kunstnerne var også villige til, hvis der efter forestillingen afholdtes fælles kaffebord, at yde bidrag til underholdningen. 
Teaterforeningen havde fastsat, at entreen for voksne ikke måtte overstige 1 kr., for børn 50 øre, men iøvrigt kunne hvert spillested fastsætte denne. Tourneen som sådan skulle selv have 50 øre pr. voksen, 25 øre pr. barn. Forestillingen gaves som foreningsforestilling, da der, hvis den var offentlig, skulle betales forlystelsesafgift. Det blev lidt senere i september bestemt, at samfundet i Øster Løgum sogn skulle beregnes for et medlemstal på 348, og der tilsendtes det et tilsvarende antal medlemskort, der skulle udfyldes med navn og adresse og derefter tilstilles medlemmerne. De kostede i første omgang 35,80 kr. til teaterforeningen. Skuespillerne fik udbetalt de $50 \%$. Plakaten kostede $4 \mathrm{kr}$., fakler 4,20 kr. Der var fælles kaffebord bagefter »Gulddåsen«, og værterne i Øster Løgum kro fik $6 \mathrm{kr}$. for kaffe til skuespillerne, der medvirkede med forskellig oplæsning og anden optræden. Entreen havde ialt givet 188 kr., så arrangementet, der utvivlsomt har været fornøjeligt, hvilede nogenlunde i sig selv.

Der var i det hele taget medvind. Den 9. december 1935 var der stor teateraften i Hovslund. Her opførte Agnete Arne Jensen-selskabet »Jul på Ravnsholt«. Sekretæren noterer »Godt Spil. Fuldt Hus«, dvs. der var solgt 144 af de dyre pladser á $2 \mathrm{kr}$., 98 af 2 . klasses billetter á $1,50 \mathrm{kr}$. og 10 børnebilletter á 50 øre, ialt gav det $435 \mathrm{kr}$., hvoraf $325 \mathrm{kr}$. gik videre til teaterselskabet. Men man kunne flotte sig: skuespillerne fik kage betalt og cigarer.

Den 27. januar 1936 blev der afholdt generalforsamling i Hovslund forsamlingshus. Formanden Rasmus Callesen aflagde beretning og understregede, at frikørslen til valget havde forøget valgdeltagelsen; han fastslog, at den store teateraften i Hovslund ved siden af grundlovsfesten i Genner og friluftsteaterforestillingen i Øster Løgum nu skulle være faste årlige fester. Der var ikke ft. $ø$ konomiske vanskeligheder, og regnskabet godkendtes uden bemærkninger.

Derefter holdt seminarielærer Eskildsen et foredrag om Sønderjyllands historie, som det hedder i sekretærens referat »betragtet og behandlet i lyset af det nye historiske syn«. Foredragsholderen "paaviste, hvorledes Folkets hele Levevis var bestemt af Blodet, Stammen, og hvor vanskeligt det var for Regenter $\mathrm{g}$ Lovbud at ændre noget deri. Befolkningslynnet blev ved at være nordisk, men Holstenerne fik den politiske Indflydelse og bevarede den efter 1721, fordi de danske Konger ønskede at bevare Holsten som Tillæg til Danmark «. Sekretæren tilføjer efter dette referat: "Foredraget var ypperligt og høstede stort Bifald«. Til slut viste Eskildsen en serie lysbilleder i tilknytning til foredraget.

Grundlovsfesten fejredes som planlagt i Genner. Musikdirektør Carl Kreutzmann, Aabenraa leverede blæsemusik for $65 \mathrm{kr}$. (transport inkl.), og lærer P. Markussen talte. Sekretæren har ikke refereret denne sammenkomst og heller intet bemærket om friluftsspillet i Øster Løgum 22. juni 1936, hvor »Karrig Nidding« opførtes. Ejner Federspiel kvitterer for Friluftsspillet i Sønderjyl- 
land; det blev til $97,25 \mathrm{kr} .+8 \mathrm{kr}$. for plakater. Der har muligvis været sammenkomst på kroen bagefter, i hvert fald fik skuespillerne kaffe (6 kr.); for assistancen fik gårdejerens kone, der havde udlånt pladsen til spillet og vel haft forskellig ulejlighed $10 \mathrm{kr}$. Selskabet kørtes videre til Varnæs; men der havde været god tilstrømning til forestillingen.

Den 15. september 1936 havde Rasmus Callesen modtaget et tilbud fra teaterselskabet om deltagelse i en novembertourné. Det blev 10. november, der holdtes teateraften i Hovslund forsamlingshus, og der spilledes Dr.jur. Sven Clausens skuespil i 3 akter "Den gamle Historie« under ledelse af skuespiller Ejner Juhl. Selskabet kom fra Bovrup, og der betaltes $50 \mathrm{kr}$. for 2 biler til transporten. Efter teaterstykket fulgte en solistafdeling med danske viser og sange med lutakkompagnement. Der spenderedes - utvivlsomt på skuespillerne -6 sodavand og 7 gange kaffe samt kage og 1 pk. cigaretter. Regning på kr. 10,80 in toto til forsamlingshusbestyreren.

Den 7. dec. 1936 afholdtes bestyrelsesmøde, og nu er der igen sekretærens referat at bygge på. Det holdtes bl.a. i anledning af indsamlingen til H.P. Hanssens Mindefond. Bestyrelsen vedtog at påtage sig opgaven. Lister blev fordelt, og det overlodes hver enkelt at antage medhjælpere.

Danske Samfunds stilling til det kommende sognerådsvalg blev drøftet, og det vedtoges, at D.S. ville indbyde alle sognets danske vælgere til et valgmøde. Et tilbud om en lille teateraften blev overladt til Genner. Til generalforsamlingen planlagdes foredrag af højkommissær Holger Andersen eller redaktør Ernst Christiansen, Flensborg.

En uge senere var der igen bestyrelsesmøde, hvor det oplystes, at indsamlingen til mindefondet havde indbragt kr. 339.

Generalforsamlingen afholdtes 5. marts. Redaktør Christiansen, Flensborg holdt foredrag om forholdene og kårene syd for grænsen. Skønt vejret var uheldigt, var der dog mødt ca. 80 mennesker. Ernst Christiansen indkasserede $20 \mathrm{kr}$. for foredraget, og det var vist den normale takst på den tid.

Grundlovsfesten blev som sædvanligt holdt i Genner, hvor Holger Andersen talte; hans honorar var kun $10 \mathrm{kr}$,, men en kørselsregning på $30 \mathrm{kr}$. kom muligvis ham tilgode. Der var visse småudgifter som kaffe til billetsælgere, men billetsalget gav helt godt - 163,55 kr. i entré.

Friluftsforestillingen - et Hostrup-skuespil i Øster Løgum 26. juni 1937 blev opgivet af hensyn til Fælleslandboforeningen i Åbenrå vel et dyrskue - og det var også nær gået galt med en forestilling i november, men så skrev Rasmus Callesen 24.okt. 1937 til Teaterselskabet: »I Anledning af Deres Meddelelse af 16.ds. angaaende November Tournéen, som vi ikke faar, da er vi bleven meget skuffede, idet vi jo var lovet alt, hvad vi ønskede, naar vi blot ville give Afkald på »Feriegæster« i Sommer til Fordel for Fælleslandboforeningen. Det- 
te udtalte Kaj Holm og Demuth, da de besøgte mig. Resultatet er blevet det helt modsatte, og nu beder jeg Dem derfor høfligst, saavidt det er Dem muligt, at udvirke, at vi dog faar vor Forestilling inden Jul.«

Henvendelsen hjalp. 8. nov. opførtes i Hovslund "Fruen vil flyve« af Erik Lassens selskab. Der blev kun solgt 103 billetter af forskellig klasse +2 børnebilletter. Indtægterne blev kun kr. 196,55, og der var annoncer i aviserne, så underskuddet måtte dækkes af bankbeholdningen.

1938 synes at have været et svagt år. Generalforsamlingen afholdtes i Hovslund Forsamlingshus 20. januar. Direktør Hammerich, Tønder skulle have talt, men blev i sidste øjeblik forhindret, hvorfor cand.mag. Troels Fink mødte i hans sted. Ved at opkræve entré til generalforsamlingen kunne man dække foredragsholderens honorar, ja, han fik endog kaffe; men kassebeholdningen var nu nede på $10-15 \mathrm{kr}$.

\section{Valgagitation 1939}

I 1939 vågner samfundet op til dåd igen. Der var 20. januar teater i Hovslund forsamlingshus. Et skuespil »Det drager« opførtes, 121 voksne og 4 børn betalte entré; arrangementet foregik gennem Sønderjydsk Teaterforening, der fik $75 \mathrm{kr}$. Der har nok været fælles kaffebord bagefter, hvor skuespillerne for eventuel medvirken fik kaffe, kager og diverse betalt $(6,30 \mathrm{kr}$.).

Ellers blev arbejdet domineret af det forestående valg 3. april 1939. Det gjaldt om at mobilisere alle danske stemmereserver. 6 . marts afholdtes bestyrelsesmøde i Ø. Løgum, hvor man vedtog at danne et forberedelsesudvalg sammensat af medlemmer fra sognets forskellige byer. De skulle mødes i Hovslund forsamlingshus mandag 13. marts for at planlægge et dansk valgfremstød.

Mødet afholdtes som vedtaget, og med sekretærens ord skulle man "gøre et forsøg på at få de flest mulige danske vælgere frem til valget, og for at nå dette vil man søge at påvirke de ligegyldige, så valgets alvor bliver klar for dem. Man vil altså prøve en husagitation, men sådan, at bestemte personer påtager sig at besøge de pågældende hjem«. Udvalget skulle også sørge for kørsel af ældre og svagelige vælgere. En anonym skænkede et tilskud på $5 \mathrm{kr}$. til valgagitationen. Der blev til 2 chauffører for valgkørsel udbetalt $82 \mathrm{kr}$., der siden refunderedes af Hammerich fra Tønder.

Grundlovsfesten i Genner afholdtes som hidtil. Entrékassen viste ved opgørelsen 155,50 kr. Talere var Chr. Demuth og amtslæge Lausten Thomsen (honorar 25 og $18 \mathrm{kr}$.). Aabenraa Spejderne, der medvirkede med orkester, fik 10 kr. til deres kasse. Der var udmærket tilslutning, og det samme gjaldt friluftsteateraftenen i Øster Løgum, hvor »Erasmus Montanus« opførtes 28. juni. 
I en årsberetning dateret 1.11.1939 til hovedorganisationen berettes om arrangementerne, der afholdtes skiftevis i de 3 forskellige distrikter, men fik tilslutning fra hele sognet. Der konkluderes til slut: "Dansk-Nazismen, der jo har været særlig virksom her i sognet, har allerede for en tid siden talmæssigt kulmineret, men er på ny tiltaget $\mathrm{i}$ aggressivitet, tilsvining af folks huse, rygter og beskyldninger mod modstandere også fremsat i deres organ, bladet »Fædrelandet«. Politiet synes at stå ret magtesløs over for denne arbejdsmetode«.

Det bevægede År 1940 indledtes med den vanlige generalforsamling i Hovslund i forbindelse med en "teateraften «, hvor filmen "Palos Brudefærd " blev spillet sammen med Gandrups »Falske Nøgler«. Det opgivne medlemstal blev nu mere realistisk opgivet til Sønderjydsk Teaterforening som 200.

\section{Dansk mobilisering i besættelsens skygge}

Med 9. april 1940 ændredes situationen afgørende. Hertil kom at hovedorganisationens formand, direktør Martin Hammerich, døde 22. april. Fællesbestyrelsen for Grænseegnens Danske Samfund fik nu gårdejer Hans Andersen, Kongsbjerg som leder. Troels Fink blev sekretær, og de fik til opgave at gennemføre udvidelsen af organisationen til hele Sønderjylland. På et møde 11.juli i Aabenraa drøftedes retningslinjerne for den nye fællesorganisation, og de mødte konstituerede sig som midlertidig hovedbestyrelse. De sønderjyske Danske Samfund opdeltes fremover i 6 kredse, idet Haderslev og Tønder amter deltes i hver to dele, der med Tønder amt og Aabenraa amt tilsammen dannede Danske Samfund.

Inden mødet 11.juli må der have været afholdt to formandsmøder i den nye organisation, hvori Rasmus Callesen må have deltaget; på et bestyrelsesmøde 28. juni 1940 i Strandhuset i Genner kunne han give oplysninger herfra. Det var bl.a. vedtaget at forny medlemslisterne og at opkræve et lille frivilligt medlemsbidrag (som norm næuntes 25 øre); alle, der tegnede sig, skulle dog have medlemskort, uanset om de betalte eller ej. Der kunne tegnes medlemmer ned til 14 år. På mødet i Strandhuset fordeltes da også medlemskort og medlemslister mellem bestyrelsens medlemmer. I den følgende tid foregik da en nytegning af medlemmer med opkrævning af kontingent. Der indkom i Øster Løgum sogn godt $270 \mathrm{kr}$.

Den 28. nov. 1940 afholdt Danske Samfund i Øster Løgum sogn generalforsamling i Hovslund forsamlingshus. Her redegjorde formanden Rasmus Callesen for medlemstegningen; der var indtegnet nøjagtig 900 medlemmer på listerne, men senere var tilmeldt nogle få. Kassereren, lærer Kristensen fremlagde regnskabet, der viste en kassebeholdning på 293,17 kr. Til fællesorganisationen 


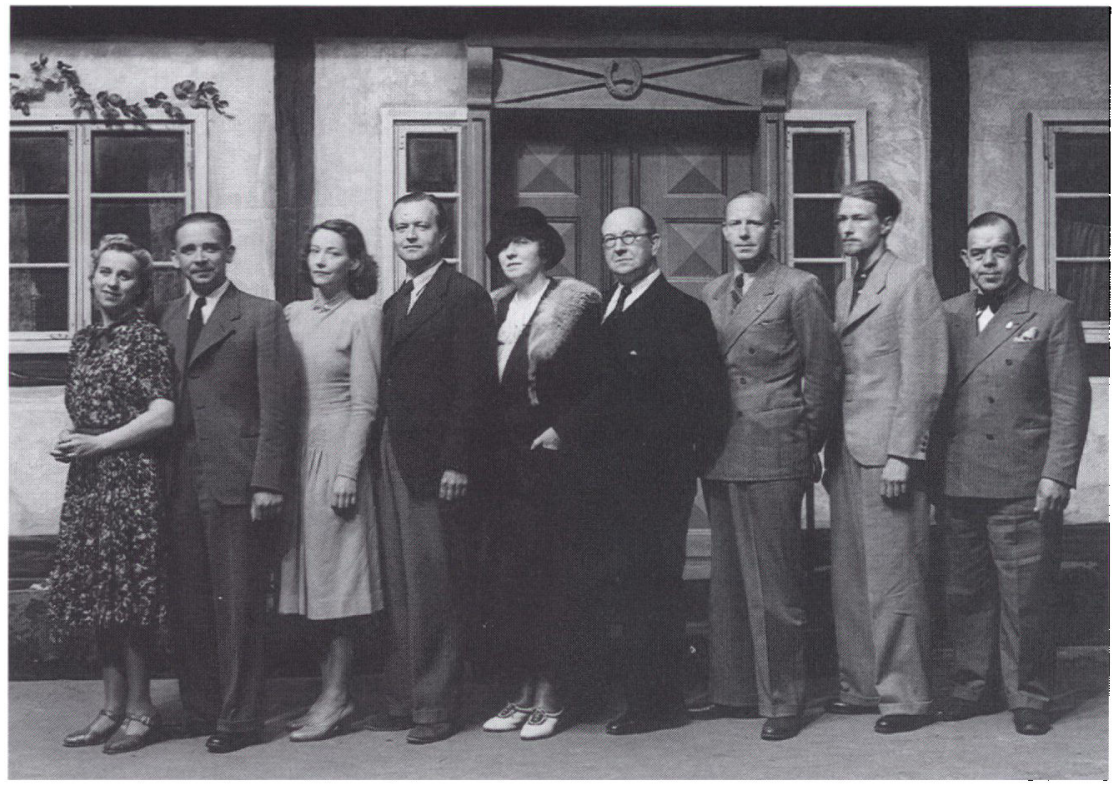

Sonderjydsk Teaterforening og de skiftende teaterturneer betod meget for programmerne i Danske Samfund. Her er vist en scene fra Chr. Demuths stykke "Jord" opfort af Kai Holm-turneen pd Nordborg Slot i 1942. Kai Holm ses yderst til hajre. Historiske Samlinger for Sonderjylland.

var indsendt $45 \mathrm{kr}$., idet der var anmodet om 5 øre pr. medlem. De nye vedtægter er formentlig blevet vedtaget på dette møde, hvor skuespiller Henrik Malberg underholdt.

Foråret 1941 bød på nye arbejdsopgaver. Det var bebudet, at der skulle afholdes kommunale valg i marts, og det kaldte på en effektiv dansk indsats. Den 8. februar samledes bestyrelsen i Øster Løgum, hvor formanden refererede fra et amtsformandsmøde og oplæste forskellige skrivelser ang. det forestående valg. Valget drøftedes, ligeledes listeopstillingen, uden at nogen bestemt fremgangsmåde vedtoges. To vognmænd antoges til kørsel for henholdsvis vestersognet og for Genner. Der planlagdes et møde med valgforberedelse til 5. marts. Foruden det lokale Danske Samfunds bestyrelse udpegedes 25-30 navngivne personer til møde i Hovslund forsamlingshus 5. marts. Hele dette apparat kom dog ikke i virksomhed, da valget aflystes ved lov af 21. februar; men det viser, at det lokale samfund var parat til at sætte ind $i$ en sådan situation.

Den 2. marts vistes i stedet Kongefilmen, vist i Hovslund forsamlingshus, antagelig arrangeret gennem Sønderjydsk Teaterforening. En friluftsteaterforestilling 12. juli gav et overskud på $41,75 \mathrm{kr}$. 
Et bestyrelsesmøde synes afholdt 25 . sept. Forinden var der dog taget stilling til et nyt tilbud fra Sønderjydsk Teaterforening, der udsendte en såkaldt »Lille Tourné« i november måned, en H.C. Andersen-aften under medvirken af Jacob Texière. Den kombineredes med generalforsamling i Hovslund forsamlingshus 28. nov., og karakteriseres af sekretæren som meget vellykket.

I 1940 udsendtes "Danske Samfunds Medlemsblad « med 3 numre, i 1941 med 2. I 1941 skiftede hovedorganisationen sekretær, idet Troels Fink afløstes af redaktør Kai Edvard Larsen. Medlemsbladet, som i 1942 var udsendt i et oplag på 45.000 eksemplarer, afløstes 1942 og 1943 af et årsskrift.

I 1942 afholdtes den årlige generalforsamling 18 . nov. i forbindelse med en teateraften. Det var igen Sønderjydsk Teaterforenings Lille Tourné, der arrangerede og opførte Wessels »Kærlighed uden Strømper«. Opførelsen høstede fortjent bifald. Der var solgt 184 billetter á $1 \mathrm{kr}$. og 20 børnebilletter. De voksne skulle desuden løse medlemskort á 10 øre. Det gav en indtægt på $215,40 \mathrm{kr}$. Skuespillernes fortæring (vel ved det fælles kaffebord) beløb sig til $6 \mathrm{kr}$. (kaffe til 5 personer, kage til 10 og 1 skål æblegrød). Skuespillerne afsluttede da også aftenen med forskellige gode smånumre, som det hedder i referatet.

Under punktet weventuelt« foreslog gårdejer Pinstrup Larsen, at der blev indbudt til en fortrolig aften, hvor en rigsdagsmand gav oplysninger om de faktiske politiske forhold i øjeblikket. Formanden lovede at forsøge at arrangere et sådant møde, som dog næppe er gennemfort.

Blandt udgifterne i 1942 findes opført $10 \mathrm{kr}$. for mærkater. Det er de smukke markater, som i 1942 udsendtes af Danske Samfund; de er vel normalt solgt helt uden om regnskabet for sognet.

Mens de kommunale valg i marts 1941 var blevet aflyst og Danske Samfunds planlagte forholdsregler i Øster Løgum som andetsteds havde måttet aflyses, stod nu et folketingsvalg for døren til afholdelse 23. marts 1943. Bestyrelsen i Øster Løgum sogn mødte fuldtalligt op 13. februar for at træffe forberedelser til et godt dansk valg. Det blev vedtaget at nedsætte et udvidet udvalg; op mod 40 personer - alle mænd undtagen frk. Fabricius - udpegedes fra alle sognets kanter. Der blev stencilleret 60 indbydelser, hvoraf 38 udsendtes gennem postvæsenet. Samtidig skete en ny opkrævning af kontingent.

19. marts holdtes der et såkaldt nationalt møde i Hovslund forsamlingshus. Redaktør Kamphøvener og formentlig nogle fra sognet talte; der er betalt kaffe for 3 talere, og kørsel til den udenbys taler. Ved selve valget sørgedes der for kørsel til valgstederne. Der var i marts 1943 til »Det danske kontor « indbetalt $135 \mathrm{kr}$., utvivlsomt medlemsbidrag beregnet for 900 medlemmer.

Valget blev en hædersdag. Valgdeltagelsen, der allerede i 1939 i Sønderjylland havde sat landsrekord, sattes yderligere i vejret med over 4000 danske stemmer flere end i 1939. 

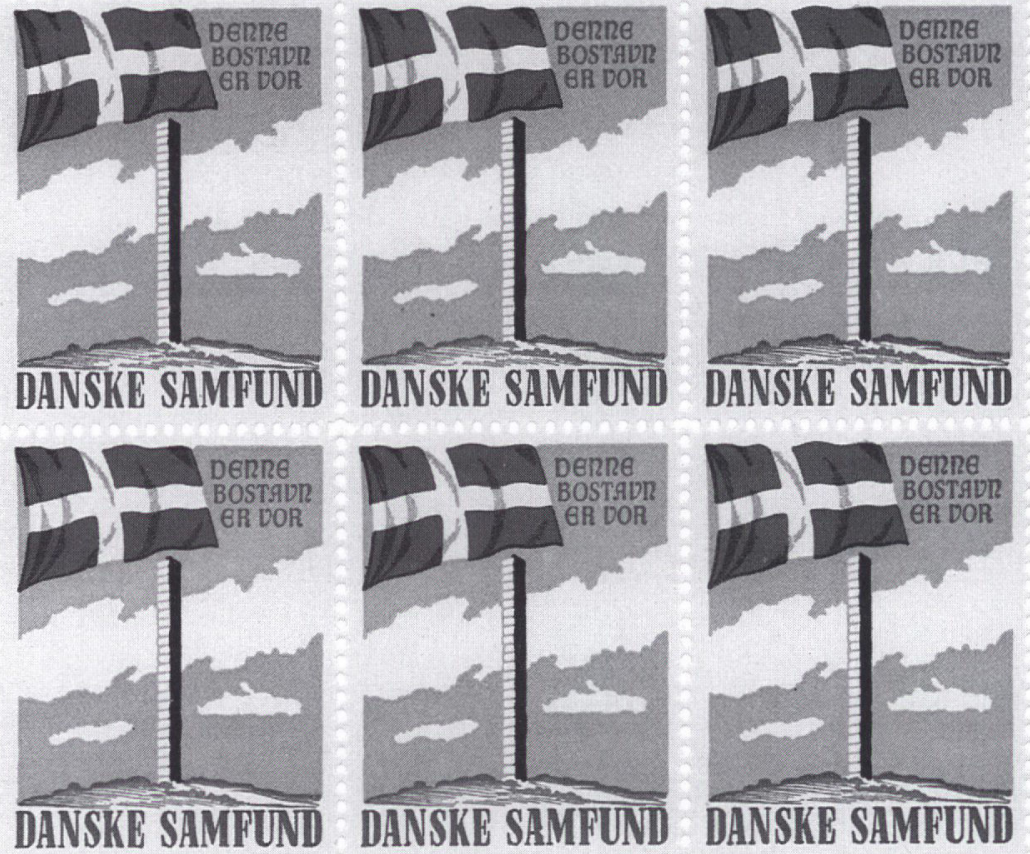

I 1942 udsendte Danske Samfund disse markater, som blev solgt $i$ stort tal. Landsarkivet $i$ Aabenraa ('museet"I).

Valget til kommuner og amtsråd, der i det øvrige land fandt sted 5.maj, aflystes derimod i Sønderjylland, da det tyske mindretal på grund af sin særlige stilling havde meddelt, at man ikke ønskede at deltage. Aflysningen skete så tidligt, at der ikke ses at være foretaget foranstaltninger fra Øster Løgums sogns Danske Samfund.

Nogen grundlovsfest i Genner synes heller ikke at være afholdt i 1943. Derimod blev friluftsteaterforestillingen i Øster Løgum gennemført 29. juni. Der opførtes en forestilling »Manden på Højriis«. Den 12.november afhoidtes generalforsamling i Hovslund forsamlingshus, hvor Rasmus Callesen som formand aflagde beretning; han oplyste, at medlemstallet var sunket fra 900 til 829 , især var tilbagegangen stor i Hovslund by og station; han fremhævede det gode forarbejde, der var gjort før valget i 1943, og som havde vist sig i det øgede danske stemmetal. 


\section{Efterkrigsår}

Efter befrielsen i maj 1945 kom der igen mere liv i sogneforeningen. I forhandlingsprotokollen noteres, at der 2.juni 1945 afholdtes det første bestyrelsesmøde efter tyskernes kapitulation, og det besluttedes at afholde grundlovsfest ved Genner strand, som det oprindeligt var skik og brug. Som talere blev foreslået højskolelærer Rosendahl, Rødding og pastor Zachariassen, Kliplev, og disse var villige. Bestyrelsesmedlemmerne fra Genner lovede at arrangere det nødvendige med hensyn til plads, billetsalg etc.

Allerede 18.juni var der nyt bestyrelsesmøde, nu ang. indsamling af naturalier og penge til danske sydslesvigere. Forhandlingsbogen oplyser herom videre: Aabenraa Amt har lovet at udrede forsyningen for juli kvartal. Øster Løgum sogns andel udgør 9 tdr. korn, $130 \mathrm{~kg}$. ost, $170 \mathrm{~kg}$. flæsk, 750 æg. Indsamlingen krævede samarbejde mellem mange. I mødet deltog derfor formændene for en lang række lokale foreninger, således Øster Løgum sogns Husholdningsforening, Hovslund og Omegns Husholdningsforening, DKB i Genner, Hovslund DKB og Ø.Løgum Sogns Husmandsforening. Det var et meget kontant udslag af samfundets arbejde. Det bestemtes, at de omtalte naturalier skulle fordeles efter byernes størrelse, og at indsamlingen skulle begynde straks.

Årsberetningen fra Øster Løgum Danske Samfund 1944-45, dateret 5. dec. 1945, giver et øjebliksbillede af tiden på begge sider af befrielsen: "Ang. foreningens aktive arbejde er der ikke meget at berette. Der har ikke foreligget særlige opgaver, som man fandt det nødvendigt at tage sig af. Valgdeltagelsen ved folketingsvalget var god, skønt tyskerne ikke havde egne kandidater at stemme på. En del af tyskerne afgav deres stemme, ligesom en del dansknazister.

Foreningens generalforsamling blev i fjor udsat på grund af lokalemangel. Hovslund forsamlingshus har været beslaglagt indtil l.oktober. Derimod lykkedes det at gennemføre en meget vellykket og meget velbesøgt grundlovsfest ved Gennerstrand med højskolelærer Rosendahl, Rødding og pastor Zachariassen, Kliplev, som talere.

Ang. den tysksprogede skole i Hovslund kan meddeles, at den endnu har livsmuligheder. 8 hjemmetyskere (deraf dog kun to blakkede, har for deltaget i dansk ungdomsarbejde) sidder fængslet, 6 er frigivet. Stemningen blandt tyskerne her $\mathrm{i}$ sognet kan nærmest betegnes som bitter, forurettet, men ikke udfordrende."

Den 22. februar 1946 var der bestyrelsesmøde hos Carsten Petersen, Øster Løgum. Det vedtoges at indbyde til opstillingsmøde til sognerådsvalget lørdag 2. marts kl. 14 i Hovslund forsamlingshus og at arbejde for »at kun renlivede 
Danskere kom på listerne.« Callesen slog til lyd for nedskrivning og indsamling af minder fra afstemningsårene 1918-20.

Fra mødet 2. marts foreligger intet referat, det faldt vel uden for Danske Samfunds egentlige arbejde; derimod afholdtes 8. maj 1946 bestyrelsesmøde i Genner Strandhus, hvori også deltog 2 repræsentanter fra Løjt sogns Danske Samfund og 2 fra Hoptrup sogns Danske Samfund. Man forhandlede om afholdelsen af en fælles grundlovsdag ved Genner Strand 5.juni 1946. Det vedtoges at afholde en sådan fest med Tage Jessen, Flensborg og konsulent Fr. Nielsen, Haderslev som talere. Sangkorene fra Løjt og Genner lovede at synge. Entreen fastsattes til $1 \mathrm{kr}$. Et eventuelt underskud skulle deles mellem de tre foreninger. Et eventuelt overskud henlægges til næste års fest eller gives til et godt formål efter senere beslutning. De nærmestboende bestyrelsesmedlemmer skulle sørge for de nødvendige forberedelser og udsmykning af pladsen. Mødet afholdtes med nævnte talere, og omkring 150 betalte entré.

Om efteråret var der igen teaterforestilling, og året efter talte de tre lokale Danske Samfund atter om en fælles grundlovsfest. Man skød højt med statsminister Knud Kristensen og seminarieforstander Bredsdorff, Tønder som talere. De skulle bestilles med det samme. Kilderne tier om dette planlagte møde, dog omtales et underskud for en grundlovsfest på $28,82 \mathrm{kr}$., der formentlig går på 1947. De nævnte høje herrer har næppe bidraget hertil.

Den 12. februar 1948 afholdtes generalforsamling i forbindelse med opførelsen af Bjørnsons »De Nygifte« og Gnudtzmanns »De Blinde«. Salen i Hovslund var fuld og forestillingen god.

Callesen aflagde en kort beretning og oplyste, at Aabenraa Danske Samfund havde vedtaget at fortsætte, medens Haderslev amt standsede. Et forslag om tilbud til en sydslesvigsk kreds om fadderskab havde endnu ikke kunnet realiseres.

\section{Nye tider}

Tiderne var ved at ændre sig. Det viste sig klart i foreningens aktiviteter. En nyvalgt bestyrelse holdt 14. juni 1948 møde i Genner Strandhus. Der var indbudt repræsentanter for Løjt og Hoptrup, men ingen var mødt. Det var tydeligt nedgangstider. Grundlovsfesten var blevet aflyst pga. det store stævne på Dybbøl. Man havde så tænkt i stedet at afholde en sommerfest 15.juni. Af angst for ringe tilslutning blev det dog opgivet, og i stedet ville man straks begynde forberedelsen til en grundlovsfest næste år; her tænkte man sig talere som kirkeminister Frede Nielsen, Sønderborg og højskolelærer Johannes Ro- 


\section{Foredragsrakken $i$ Hovslund Forsamlingshus 1946.}

10./2. Højskolelærer Truelsen, Snoghøj.

21./2. Lerer P. Markussen, Graasten.

24./3. Pastor Ebbesen, Døstrup: Oplesning.

15./6. Genforeningsfest. Kaptajn Bartholdy.

26/9. Seminarielarer Claus Eskildsen, Tender.

8./10. Efteraarsmøde Kl. 14,30: Pastor Nielsen, Højer og Forst. Damgaard-Nielsen, Ryslinge.

14./11. En Taler fra Sydslesvig.

Møderne begynder Kl. 8, saa vidt muligt pracis.

D. s. эснміотs tark, vojens

Program for foredragsrakken i Hovslund forsamlingshus 1946.

sendahl, nu Andelshøjskolen, Middelfart. Ligeledes vedtoges at forsøge at indbyde et gymnastikhold og et håndboldhold fra sognet eller amtet.

Den 2. december 1948 afholdtes en ringe besøgt generalforsamling. Der var kun mødt 25 deltagere, og endog flere af bestyrelsen manglede, bemærker sekretæren. Der vistes ialt 4 film fra Dansk Filmcentral, bl.a. "For Folkets Skyld «, "Skoleskibet Danmark« og "Hvad Fatter gør«. Formanden kunne nøjes med få minutter til sin beretning.

Og så kom året 1949. Bestyrelsesmøde afholdes 17. februar i Øster Løgum skole. Rasmus Callesen, Lerskov, ønskede at fratræde som formand, og i stedet valgtes lagerist Andreas Jensen. Det blev vedtaget ikke at afholde grundlovsfest ved Gennerstrand, men at tilslutte sig samarbejde med Aabenraa bys Danske Samfund om »en stor fest«. Det vedtoges yderligere at søge at få en friluftsforestilling i den kommende sommer.

I det hele taget fungerede teaterforestillingerne takket være Sønderjydsk Teaterforening længst. Endnu i 1952 havde Danske Samfund i Øster Løgum sogn - efter regnskabet - kontakt med Teaterforeningen.

Protokollen var ved at ebbe ud. Efter indførslen om bestyrelsesmødet i Øster 
Løgum skole gik der nu 5 år, indtil næste notat blev indført i forhandlingsprotokollen. 14. april 1954 noterer lærer Kristensen: "Efter ovenstående gik Dansk Samfund i ro. Der har ikke siden været afholdt bestyrelsesmøder eller generalforsamling. Kun samarbejdet med Sønderjydsk Teaterforening er blevet fortsat, og de fleste år har forskellige tourneer besøgt forsamlingshuset, og friluftstourneen har spillet i Øster Løgum. 1953 overdroges den til Hovslund Gymnastikforening og spillede på idrætspladsen.«

Sådan lyder de sidste ord i forhandlingsprotokollen. Resten er blanke sider. Tavsheden bekræftes af et indlagt maskinskrevet bilag underskrevet af 5 bestyrelsesmedlemmer:

"Danske Samfund for Øster Løgum sogn har nu siden 1953 været stillet helt $i$ bero. Der er ikke afholdt valg af nye bestyrelsesmedlemmer eller noget som helst andet vedrørende foreningen.

Foreningen havde ved standsningen en lille kassebeholdning, der med tilskrevne renter i dag beløber sig til 194,46 kr.

Det findes meningsløst at lade dette lille beløb fortsat stå hen til ingen nytte. Undertegnede tilbageværende bestyrelsesmedlemmer har derfor vedtaget at fordele det mellem sognets to forsamlingshuse efter forholdet 7:11, så Genner forsamlingshus får ... 75,60 kr. Hovslund forsamlingshus ... 118,86 kr.

Beløbene udbetales af Jens Kristensen til formanden for hvert forsamlingshus mod dennes kvittering, der opbevares indtil videre.
Andreas P. Jensen
I. Jessen
Johannes Pedersen
Kr. Clausen
Jens Good."

Disse kvitteringer er endnu bevaret. De viser, at den endelige afregning fandt sted i 1968.

Danske Samfund i Øster Løgum sogn havde sluttet sit virke. At foreningen i nogle af årene har haft væsentlig national betydning vil næppe blive bestridt. Der blev sat en del i gang rundt om i forsamlingshusene, men set med nutidens øjne var det småt og primitivt. Billigt skulle den slags arbejde være, som tallene $i$ artiklen viser. Opførelsen af de mange skuespil og indkvarteringen af skuespillerne i hjemmene har sikkert også givet tiltrængte kulturpust $i$ et sogn, der ikke var forvænt med den slags.

Alligevel må det fremhæves, at Danske Samfund ikke var alene om arbejdet. En foredragsforening for Hovslund og Omegn virkede omkring det i 1934 indviede forsamlingshus. Foreningens forhandlingsbog for årene 1942-48 fandtes også i Jens Kristensens gemme. Den begynder således: "21. nov. 1942 afholdt foredragsforeningens bestyrelse møde sammen med gymnastikforeningens bestyrelse for at lægge plan for det kommende års møder og talere.« Det 
er delvis de samme personer, vi møder i denne foredragsforening. I hvert fald var der som sekretær Jens Kristensen, og der må have været noget skrivearbejde, for der kom mange nej'er på henvendelser til foredragsholdere, ligesom der skulle trykkes medlemskort med påtrykt program for foredragsrækker $\mathrm{i}$ Hovslund forsamlingshus. Det sidste foreliggende program er for 1950.

Danske Samfund, Foredragsforeningen, Gymnastikforeningen og Husholdningsforeningen virkede ofte side om side, et vidnesbyrd om en betydelig folkelig virksomhed $\mathrm{i}$ et sønderjysk sogn $\mathrm{i}$ nogle vanskelige år. Det var foreninger af denne art, som var med til at bære landsdelen gennem 30'ernes og krigsårenes udfordringer. 


\section{LITTERATUR}

Hans Andersen: Da der blev kaldt til samling. Oprettelsen af De danske Samfund i grænseområdet i 1933, i: Nord-Syd. 2. årgang, 1957-58 s. 204-211.

Hans Andersen: De sønderjydske Danske Samfund, i: SJy MSkr 1965 s. 265-279.

Peter Kr. Iversen: Jens Kristensen, Østerløgum (nekrolog), i: SJy Årb 1987 s. 206-207.

\section{KILDER}

Dansk Samfund for Øster Løgum Sogn: forhandlings- og regnskabsprotokoller med bilag (Landsarkivet i Aabenraa).

Hovslund og Omegns foredragsforening: forhandlingsprotokol (Landsarkivet i Aabenraa). 